\title{
PDE2, a component of the NO/cGMP signalling in the hippocampus
}

\author{
Isabel Schönle ${ }^{1 *}$, Angela Neitz², Thomas Mittmann², Doris Koesling ${ }^{1}$, Evanthia Mergia ${ }^{1}$ \\ From 5th International Conference on cGMP: Generators, Effectors and Therapeutic Implications \\ Halle, Germany. 24-26 June 2011
}

\section{Background}

NO/cGMP-mediated signal transduction is involved in synaptic plasticity in various brain regions. NO effects are transduced by the NO receptor guanylyl cyclase (NO-GC) that exists in two isoforms, NO-GC1 and NO-GC2, with indistinguishable regulatory properties. Mice deficient in either NO-GC1 or NO-GC2 revealed that both NO-GC isoforms are required for LTP indicating the existence of two separated NO/cGMP pathways. Recently, we demonstrated a presynaptic role of $\mathrm{NO} / \mathrm{cGMP}$ in facilitation of glutamate release and indentified eNOS and NO-GC1 as the participating enzymes. Yet, the involved cGMP-hydrolysing phosphodiesterases (PDE) remained unknown.

\section{Results}

Here we demonstrate that PDE2 accounts for $50 \%$ of cGMP-hydrolysing activity in hippocampal homogenates. In hippocampal slices of WT, NO-GC1 and NOGC2 KO mice, PDE2 inhibition increased NMDAinduced cGMP levels.

\section{Conclusion}

This suggests PDE2 as a component of both NO-GC1and NO-GC2-mediated signalling pathways. Moreover we analyzed the physiological role of the PDE2 on glutamatergic transmission in the hippocampal CA1 region by single-cell recordings in acute slices.

\section{Author details}

'Institute of Pharmacology, Medical School, Ruhr-University Bochum, Bochum, Germany. ${ }^{2}$ Institute of Physiol. \& Pathophysiol., Univ. Med.-Center of the Joh.-Gutenberg-Univ. Mainz, Germany.

\footnotetext{
* Correspondence: isabel.schoenle@ruhr-uni-bochum.de

'Institute of Pharmacology, Medical School, Ruhr-University Bochum, Bochum, Germany

Full list of author information is available at the end of the article
}

Published: 1 August 2011

doi:10.1186/1471-2210-11-S1-P63

Cite this article as: Schönle et al:: PDE2, a component of the NO/cGMP signalling in the hippocampus. BMC Pharmacology 2011 11(Suppl 1):P63.
Submit your next manuscript to BioMed Central and take full advantage of:

- Convenient online submission

- Thorough peer review

- No space constraints or color figure charges

- Immediate publication on acceptance

- Inclusion in PubMed, CAS, Scopus and Google Scholar

- Research which is freely available for redistribution 